\title{
PERBEDAAN ARANG BIJI KELOR DAN ARANG BIJI SALAK DALAM PENURUNAN KADAR TIMBAL (Pb) PADA AIR LIMBAH
}

\author{
THE DIFFERENCE OF MORINGA SEEDS CHARCOAL AND BARK SEEDS CHARCOAL \\ IN DECREASING LEVEL OF RECIPROCAL (PB) IN WASTE WATER
}

\author{
Abdi Iswahyudi Yasril \\ Departemen BiostatistikadanKependudukanFakultasKesehatanMasyarakat \\ Universitas Airlangga \\ iswahyudiabdi2893@gmail.com
}

\begin{abstract}
Moringa seeds and bark seeds have economic value that is made into charcoal as an adsorbent to heavy metals. Potential charcoal moringa seeds and seed bark lies on active carbon. Activated charcoal effectively use activator. The aim of research to find out difference charcoal moringa seed and charcoal bark seed in the decline of Pb in wastewater. Study was a quasiexperimental design using post testgroup.Object of research is charcoal moringa seeds and bark seeds activated grains with $\mathrm{Al}_{2}\left(\mathrm{SO}_{4}\right)_{3} 1 \%, 3$ treatment $(10 \mathrm{gr}, 15 \mathrm{gr}$ and $20 \mathrm{gr})$ and 8 replications based on a formula $(t-1)(r-1) \geq 15$ on absorption of $P b$. To know difference charcoalmoringa seed and charcoal bark seed in the decline of Pb in wastewater conducted by IndependentTtest and ANOVA test with $\alpha 95 \%$. Results of study average weight $10 \mathrm{gr} \mathrm{Pb}$ decrease of charcoal moringa seeds are 5.2335ppm and average reduction of $83.6958 \%$. While average decline of charcoal bark seeds are 4.7055ppm average reduction of $75.2518 \%$. $15 \mathrm{gr}$ weight average reduction of charcoal moringa seeds against $P b$ is 5.5166ppm and average reduction of $88.2236 \%$ while average decrease of charcoal bark seeds are 5.3950ppm average reduction of $86.2786 \%$. 20gr weight of average reduction of charcoal moringa seeds to waste $\mathrm{Pb}$ is 5.9103ppm and average reduction of $94.5206 \%$ while the average decrease of charcoal bark seeds are 5.7476ppm,average reduction 91.9178\%. There are differences in decreased levels of $\mathrm{Pb}$ in wastewater by using charcoal moringa seed and charcoal seed bark. For absorption of $\mathrm{Pb}$ in wastewater are advised to use charcoal moringa seeds $20 \mathrm{gr}$.
\end{abstract}

Keywords : reciprocal(Pb).,waste water, moringa seeds (MoringaOleifera), bark seeds (Salaccazalacca). 


\begin{abstract}
ABSTRAK
Biji kelor dan biji salak mempunyai nilai ekonomis yaitu dibuat menjadi arang aktif sebagai adsorben terhadap logam berat. Potensi arang biji kelor dan biji salak terletak pada karbon aktifnya. Arang aktif efektifmenggunakan aktifator. Tujuan penelitian untuk mengetahui perbedaan arang biji kelor dan arang biji salak dalam penurunan $\mathrm{Pb}$ pada air limbah.Penelitian bersifat eksperimen semu menggunakan post test group design. Objek penelitian adalah arang biji kelor dan arang biji salak teraktivasi dengan $\mathrm{Al}_{2}\left(\mathrm{SO}_{4}\right)_{3} 1 \%, 3$ perlakuan (10gr, 15gr dan 20gr) dan 8 ulangan berdasarkan rumus $(\mathrm{t}-1)(\mathrm{r}-1) \geq 15$ terhadap penyerapan $\mathrm{Pb}$. Untuk mengetahui perbedaan arang biji kelor dan arang biji salak dalam penurunan $\mathrm{Pb}$ pada air limbah dilakukan dengan uji T Independen dan uji Anova dengan $\alpha 95 \%$.Hasil penelitian berat $10 \mathrm{gr}$ rata-rata penurunanPb dari arang biji kelor adalah $5.2335 \mathrm{ppm}$ dan rata-rata efesiensi penurunan $83.6958 \%$ sedangkan rata-rata penurunan dari arang biji salak adalah $4.7055 \mathrm{ppm}$ dan rata-rata efesiensi penurunan $75.2518 \%$. Berat $15 \mathrm{gr}$ rata-rata penurunan dari arang biji kelor terhadap $\mathrm{Pb}$ adalah 5.5166ppm dan rata-rata efesiensi penurunan $88.2236 \%$ sedangkan rata-rata penurunan dari arang biji salak adalah 5.3950ppm dan rata-rata efesiensi penurunan $86.2786 \%$. Berat 20gr rata-rata penurunan dari arang biji kelor terhadap limbah $\mathrm{Pb}$ adalah 5.9103ppm dan rata-rata efesiensi penurunan $94.5206 \%$ sedangkan rata-rata penurunan dari arang biji salak adalah 5.7476ppm dan rata-rata efesiensi penurunan $91.9178 \%$. Terdapat perbedaan penurunan kadar $\mathrm{Pb}$ pada air limbah dengan menggunakan arang biji kelor dan arang biji salak. Untuk penyerapan $\mathrm{Pb}$ pada air limbah disarankan menggunakan arang biji kelor 20gr.
\end{abstract}

\title{
Kata Kunci : timbal (Pb), air limbah, bijikelor (Moringaoleifera), bijisalak (Salacca zalacca).
}

\section{PENDAHULUAN}

Industri percetakan adalah sebuah industri untuk memproduksi secara massal tulisan dan gambar, terutama dengan tinta di atas kertas menggunakan sebuah mesin cetak yang merupakan sebuah bagian penting dalam penerbitan dan percetakan. ${ }^{1}$

Kegiatan suatu industri adalah proses pengolahan suatu bahan baku menjadi bahan setengah jadi atau bahan jadi untuk keperluan manusia.Disamping itu industri percetakan mempunyai potensi menghasilkan limbah cair yang dapat mencemari lingkungan hidup. Limbah cair adalah limbah dalam wujud cair yang dihasilkan oleh kegiatan/ usaha atau industri yang dibuang ke lingkungan dan diduga dapat menurunkan kualitas lingkungan. ${ }^{2}$

Pada umumnya limbah cair industri terutama pada percetakan terjadi akibat pencucian plat film dan peralatan cetak berupa sisa-sisa tinta, terpentin, bensin, dan detergen. Limbah cair industri percetakan banyak mengandung bahan kimia organik yang sulit didegradasi secara langsung. ${ }^{3}$ Limbah cair industri yang berasal dari industri percetakan, merupakan salah satu limbah yang mengandung banyak pencemar yang sulit terurai di lingkungan. ${ }^{4}$ Limbah cair ini banyak mengandung bahan kimia berbahaya yaitumengandung logam berat seperti krom $(\mathrm{Cr})$, cobalt $(\mathrm{Co})$, mangan $(\mathrm{Mn})$, cadmium (Cd) dan timbal (Pb) (salah satu yang terdapat pada tinta industri percetakan yang dapat larut ke dalam berbagai bahan pengikat.

Di dalam limbah cair industri percetakan berupa sisa tinta cetak mengandung berbagai parameter pencemar antara lain adalah warna. Warna yang ada di dalam limbah cair percetakan yang langsung dibuang tanpa pengolahan akan menggangu kehidupan aquatik badan air penerima, karena akan menghambat proses fotosintesis dan meyebabkan gangguan ekosistem. Limbah percetakan sangat berpengaruh tidak hanya pada air permukaan sekitar tempat percetakan, tetapi juga dampak jangka panjang pada sistem ekologi air. ${ }^{4}$ 
Kandungan zat warna terutama pada tinta berisikan pelarut, pigmen, celupan, resin dan pelumas, sollubilizer, surfaktan, memungkinkan penyebaran yang mudah, surfaktan juga menurunkan tekanan antar permukaan antara dua cairan, materi-materi partikuler, pemijar. ${ }^{5}$ Salah satu jenis tinta yang digunakan untuk mencetak adalah tinta berpigmen yang mengandung unsurunsur yang memperkuat peresapan. Pigmen tersebut mengandung salah satu logam yang beracun yaitu timbal $(\mathrm{Pb}){ }^{6}$

Timbal dan gas-gas lainnya seperti $\mathrm{Cr}$ dan $\mathrm{Cd}$, merupakan logam yang berasal dari zat warna yang terdapat dalam tinta yang digunakan untuk menghasilkan percetakan. Pada waktu pencetakan media, logam tersebut akan dilepaskan ke udara sehingga bahan-bahan kimia di lingkungan kerja akan meningkat terutama pada perusahaan media cetak, sehingga dapat mengganggu keselamatan dan kesehatan pekerja. ${ }^{6}$

Logam $\mathrm{Pb}$ merupakan logam yang paling banyak ditemukan dalam air limbah pada industri percetakan. $\mathrm{Pb}$ termasuk kedalam kelompok logam-logam golongan IV-A pada tabel periodik unsur kimia. Mempunyai nomor atom (NA) 82 dengan bobot atau berat (BA) 207,2 adalah suatu logam berat berwarna kelabu kebiruan dan lunak dengan titik leleh $327{ }^{\circ} \mathrm{C}$ dan titik didih $1.620{ }^{\circ} \mathrm{C}$. Pada suhu $550-600{ }^{\circ} \mathrm{C}$. $\mathrm{Pb}$ menguap dan membentuk oksigen dalam udara membentuk timbal oksida. Bentuk oksidasi yang paling umum adalah timbal (II). $\mathrm{Pb}$ sangat rapuh dan mengkerut pada pendinginan, sulit larut dalam air dingin, air panas dan air asam timah hitam dapat larut dalam asam nitrit, asam asetat dan asam sulfat pekat. ${ }^{7}$

Ada beberapa bentuk keracunan timbal, yaitu : (1) Keracunan akut, masuknya senyawa timbal yang larut dalam asam atau inhalasi uap timbal. Efek adstringen menimbulkan rasa haus dan rasa logam disertai rasa terbakar pada mulut. Gejala lain ialah mual, muntah serta gangguan sistem syaraf pusat berupa gejala ringan,yaitu kebas dan vertigo. Gejala yang berat menyebabkan pergelangan tangan terkulai (wrist drop) dan pergelangan kaki terkulai (foot drop). (2) Keracunan subakut, berupa gelisah, lemas dan depresi. Penderita sering mengalami gangguan system pencernaan. (3) Keracunan kronis, lebih sering dialami para pekerja yang terpapar timbal pada berbagai industri, sehingga keracunan ini disebut sebagai penyakit industri, seperti penyusun huruf pada percetakan, pengatur komposisi media cetak, pembuat huruf mesin cetak, pabrik cat, petugas pemasang pipa gas. Keracunan kronis dapat mempengaruhi sistem syaraf dan ginjal, sehingga menyebabkan anemia dan kolik, mempengaruhi fertilitas, menghambat pertumbuhan janin.$^{8}$

Masuknya logam berat ke dalam lingkungan membuat manusia meneliti dan berfikir untuk melakukan pengolahan terhadap limbah $\mathrm{Pb}$. Beberapa proses dan teknologi yang telah diaplikasikan dalam pengolahan air limbah yang mengandung logam berat dalam air limbah industri, seperti: (1) Pengendapan, koagulasi dan flokulasi; (2) Proses pertukaran ion / resin penukar ion (Ion Exchange); (3) Proses Elektrokimia (oksidasi-reduksi); Biodsorbsi (penyerapan dengan mikroorganisme/ biologi). ${ }^{9}$

Teknologi pengolahan limbah yang banyak digunakan pada masa ini adalah teknologi biosorben. Biosorben merupakan proses penyerapan senyawa-senyawa organik, ion atau molekul-molekul pada permukaan bahan. Jenis material yang mempunyai potensi sebagai bahan penyerap adalah limbah pertanian seperti sekam padi, ampas tebu, tongkol jagung, biji salak ,biji kelor. ${ }^{10}$

Salak (Salacca zalacca) merupakan tanaman asli Indonesia yang buahnya banyak digemari masyarakat karena rasanya manis, renyah dan kandungan gizi yang tinggi. Konsumsi per kapita salak pada tahun 2008 sebesar 1,64 kg/kap/th, dengan tingkat kerusakan rata-rata $15 \%$, maka keperluan salak per tahun adalah sebesar $420 \mathrm{ribu}$ ton/tahun atau $35 \mathrm{ribu}$ ton/bulan. ${ }^{11}$ Banyak masyarakat yang mengkonsumsi salak, dan banyak sampah salak yang terbuang tanpa ada pengolahan terutama pada biji salak, pemanfaatan biji dari buah salak kurang mendapat perhatian 
dikarenakan bentuknya yang keras dan kasar.

Kandungan yang terdapat pada salak adalah Vitamin C 31, 92\%; karbohidrat 21,35\%; Protein 0,97\%; Lemak 0,17\% dan kadar air adalah sebesar 76,67\%. Selain itu salak termasuk dalam angiospermae yaitu tumbuhan berbiji tertutup, yaitu tumbuhan yang memiliki struktur dinding sel yang kaku yang tersusun dari senyawa selulosa. ${ }^{12}$ Selulosa adalah komponen struktur utama pada dinding sel tumbuhan. Selulosa dapat didegradasi oleh enzim menjadi beberapa unit glukosa dan biasanya dihidrolisis dengan menggunakan asam kuat. Selulosa mempunyai kemampuan untuk mengadsorpsi logam berat. Selain itu, berdasarkan percobaan sebelumnya telah diketahui bahwa kayu dan komponenya, seperti selulosa, lignin, hemiselulosa, dan sebagainya, telah digunakan dalam industri penjernihan air untuk menghilangkan logam berat seperti $\mathrm{Cu}(\mathrm{II}), \mathrm{Pb}(\mathrm{II}), \mathrm{Cd}(\mathrm{II})$, Cr(III) dan sebagainya. Untuk meningkatkan nilai ekonomis dari tumbuhan ini maka salah satunya biji salak dijadikan sebagai adsorben. Menurut penelitian Aji, B. K. dan Kurniawan, F, biji salak dimanfaatkan sebagai absorben $\mathrm{Cr}(\mathrm{VI})$ dengan menggunakan metode kolom yang diharapkan mampu mengoptimalkan usaha dari pengolahan limbah lingkungan, Adsorpsi $\mathrm{Cr}(\mathrm{VI})$ menggunakan adsorben serbuk biji salak. Biji salak dipreparasi hingga menjadi serbuk. Serbuk biji salak dicuci dengan aqua DM dan metanol. Konsentrasi ion logam ditentukan dengan Spektrofotometer UV-Vis. Kondisi optimum adsorpsi ion $\mathrm{Cr}(\mathrm{VI})$ diperoleh waktu kontak 60 menit dengan ukuran partikel $125 \mu \mathrm{m}$, dan konsentrasi ion logam $100 \mathrm{mg} / \mathrm{L}$. Kapasitas penyerapan optimum ion $\mathrm{Cr}(\mathrm{VI})$ oleh serbuk biji salak adalah $0,59 \mathrm{mg} / \mathrm{g} .{ }^{12}$

Kelor (Moringa oleifera. Lamk) termasuk jenis tanaman perdu yang memiliki ketinggian batang 7-11 meter. Batang kayunya getas (mudah patah) dan cabangnya jarang tetapi mempunyai akar yang kuat. Daunnya berbentuk bulat telur dengan ukuran kecil-kecil bersusun majemuk dalam satu tangkai. ${ }^{13}$ Kelor 14 menjadi sumber antioksidan alami karena kelor mengandung berbagai jenis senyawa antioksidan seperti askorbat acid, flavonoid, phenolic dan karotenoid.

Biji kelor dapat digunakan sebagai adsorben bahan organik, koagulan pada pengolahan air, dan zat polimer organik yang tidak berbahaya, dan biji kelor juga merupakan tumbuhan biji tertutup yang mengandung selulosa. Biji kelor diketahui mengandung polielektrolit kationik dan flokulan alamiah dengan komposisi kimia berbasis polipeptida, mengandung asam amino sehingga dapat mengkoagulasi dan flokulasi kekeruhan air. Biji kelor berperan sebagai pengendap (koagulan) dengan hasil yang memuaskan. Bahkan biji kelor juga berkhasiat sebagai anti bakteri . Berdasarkan penelitian di Universitas Gajah Mada Yogyakarta, serbuk biji kelor mampu membersihkan $90 \%$ dari total bakteri E. coli dalam satu liter air sungai dalam waktu 20 menit. $^{13}$

Biji buah kelor mengandung zat aktif rhamnosyloxy - benzil-isothiocyante, yang mampu mengadsorbsi dan menetralisir partikel-partikel lumpur serta logam yang terkandung dalam limbah tersuspensi dengan partikel kotoran yang melayang dalam air.Serbuk biji kelor dapat memberikan efisiensi penurunan pada logam berat $(\mathrm{Pb}, \mathrm{Cu}, \mathrm{Mn}, \mathrm{Zn})$. Efektifitas koagulasi dari serbuk biji kelor ditentukan oleh kandungan protein kationik bertegangan rapat dengan berat molekul sekitar 6,5 kdalton. ${ }^{14}$

Biji kelor diketahui mengandung polielektrolit kationik dan flokulan alamiah dengan komposisi kimia berbasis polipeptida, mengandung asam amino sehingga dapat mengkoagulasi dan flokulasi kekeruhan air.

PT. Padang Graindo Mediatama merupakan industri percetakan yang ada di kota Padang, yang mana perusahaan ini menghasilkan limbah cair yang berasal dari bahan pelarut, bahan pencair, bahan pengering dan tinta. Limbah tersebut mengandung logam berat seperti $\mathrm{Cr}, \mathrm{Cd}$, dan $\mathrm{Pb}$. PT. Padang Graindo Mediatama belum ada melakukan pengolahan untuk limbah cair, sehingga akan sangat 
berbahaya terutama bagi pekerja yang bekerja di perusahaan tersebut, dan akan membahayakan masyarakat jika langsung dibuang ke lingkungan. Maka perlu dilakukan pengolahan salah satunya dengan cara adsorpsi. Biji kelor dan biji salak merupakan salah satu adsorben yang dapat menurunkan kadar logam berat, dan dapat dijadikan alternatif teknologi tepat guna untuk menurunkan logam berat terutama $\mathrm{Pb}$ dalam industri percetakan seperti PT. Padang Graindo Mediatama.

Berdasarkan uraian di atas, maka peneliti tertarik untuk melakukan penelitian tentang perbedaan penggunaan arang biji kelor dan arang biji salak dalam penurunan kadar timbal $(\mathrm{Pb})$ pada air limbah di PT. Padang Graindo Mediatama. Berdasarkan uraian pada latar belakang diatas, maka tujuan penelitian ini adalah mengetahui perbedaan penggunaan arang biji kelor dan arang biji salak dalam penurunan kadar $\mathrm{Pb}$ pada air limbah.

\section{METODE PENELITIAN}

Penelitian ini bersifat eksperimen semu, yaitu melakukan perbedaan penggunaan arang biji kelor dan arang biji salak dalam penurunan kadar timbal $(\mathrm{Pb})$ pada air limbah dengan perlakuan berat (gr) yaitu $10 \mathrm{gr}, 15 \mathrm{gr}$ dan $20 \mathrm{gr}$ yang masingmasing dilakukan 8 pengulangan berdasarkan rumus $(\mathrm{t}-1)(\mathrm{r}-1) \geq 15$

Desain penelitian menggunakan post test group desain sehingga dapat dilihat besaran perbedaan antara sebelum dan sesudah memanfaatkan adsorben arang biji kelor dan arang biji salak.Objek penelitian adalah biji kelor dan biji salak yang telah dilakukan proses karbonisasi sehingga menjadi arang melalui cara pembakaran selanjutnya di aktivasi dengan menggunakan $\mathrm{Al}_{2}\left(\mathrm{SO}_{4}\right)_{3} 1 \%$.

Pembuatan arang biji kelor dan biji salak. Biji kelor dan biji salak dicuci dengan air sampai bersih, lalu dikeringkan. Kemudian Biji kelor dan biji salak tersebut ditumbuk dan dicacah sedikit terlebih dahulu untuk memudahkannya dalam proses pembakaran, kemudian biji kelor dan biji salak di bakar di dalam kaleng yang berbeda. Pembakaran biji kelor dan biji salak dilakukan secara bergantian, namun perlakuan pembakaran sama. Tutup kaleng bagian atasnya dan bagian bawahnya dilubangi dengan diameter $4 \mathrm{~mm}$ sebanyak empat buah dengan jarak yang sama (10 $\mathrm{cm})$. Kaleng ditempatkan di atas batu yang disusun seperti tungku dan dilakukan pembakaran. Selama api menyala biji kelor dan biji salak ditambahkan sedikit demi sedikit sampai setinggi permukaan kaleng. Selanjutnya kaleng ditutup dengan kain basah yang dilapisi dengan penutup logam dengan rapat. Selanjutnya dibiarkan dingin selama satu malam. Arang Biji kelor dan arang biji salak hasil pembakaran ditumbuk kemudian dicuci dengan air hingga $\mathrm{pH}$ netral dan dikeringanginkan pada suhu kamar selama satu minggu sebelum digunakan.

Pembuatan arang biji kelor dan biji salak yang diaktifasi dengan $\mathrm{Al}_{2}\left(\mathrm{SO}_{4}\right)_{3}$ $1 \%$.Arang biji kelor dan biji salak yang sudah ditumbuk kemudian direndam dalam $\mathrm{Al}_{2}\left(\mathrm{SO}_{4}\right)_{3} \quad 1 \%$ selama 3 jam. Kemudian dicuci dengan air hingga $\mathrm{pH}$ netral dan dikeringkan pada suhu kamar selama satu minggu sebelum digunakan.Perlakuan arang biji kelor dan biji salak yang sudah teraktifasi. Sediakan 3 buah kromatografi kolom lalu dimasukkan kapas ke dalam masing-masing kromatgrafi kolom. Lalu masukkan arang biji kelor dan arang biji salak teraktifasi ke dalam masingmasing kromatografi kolom sesuai dengan kebutuhan (lakukan masing-masing pada ketiga kolom) yaitu 10 gr, 15 gr dan 20 gr. Kemudian limbah media cetak yang mengandung logam $\mathrm{Pb}$ dimasukkan ke dalam kolom secara perlahan, kemudian biarkan sebentar sampai penyerapan sempurna. Hasil eluat di tampung dengan gelas kimia yang masing-masing sudah diberi label dan di saring.

Pengukuran konsentrasi logam berat pada semua perlakuan dilakukan secara Spektrofotometer Serapan Atom (SSA). Banyaknya ion logam yang diserap biosorben adalah perbedaan konsentrasi ion logam sebelum dan sesudah ion logam dilewatkan pada kolom kromatografi. Analisis univariat dilakukan dengan melihat mean, nilai minimum, nilai maksimum dari 
masing-masing parameter, dan efesiensi penyerapan dihitung dari konsentrasi awal sebelum dimasukan ke kolom dikurangi konsentrasi setelah dilewatkan ke dalam kolom, dibagi dengan konsentrasi awal dikali $100 \%$. Efesiensi penyerapan dapat ditulis sebagai berikut :

\section{Efisiensi penyerapan}

$$
=\frac{C o-C}{C o} \times 100 \%
$$

Keterangan :

$$
\begin{aligned}
& C o=\text { Konsentrasi awal } \\
& C=\text { Konsentasi setelah perlakuan }
\end{aligned}
$$

Sementara itu, analisis bivariat dilakukan untuk melihat perbedaan antara masing-masing berat atau dua kelompok data dilakukan dengan metode uji $\mathrm{T}$ Independen dan juga dilakukan uji anova untuk menguji apakah masing-masing ketiga perlakuan mempunyai rata-rata yang sama dengan derajat keperayaan $95 \%$ atau $\alpha=5 \%(0,05)$. Jika diperoleh $p \leq \alpha(0,05)$, maka Ho ditolak yang berarti rata-rata ketiga perlakuan tersebut memang berbeda nyata. Untuk melihat mana saja perlakuan yang berbeda dan mana yang tidak berbeda dilakukan test Bonferroni. Jika diperoleh $\mathrm{p}$ $\leq \alpha(0,05)$, maka Ho ditolak berarti ada perbedaan besar serapan adsorben arang biji kelor dan arang biji salak pada ukuran berat terhadap logam $\mathrm{Pb}$.

\section{HASIL DAN PEMBAHASAN}

Setelah dilakukan pemeriksaan limbah percetakan PT. Padang Graindo Mediatama dengan menggunakan SSA, maka dipeoleh logam $\mathrm{Pb}$ dengan konsentrasi 6.253 ppm. Hasil penelitian terhadap penggunaan arang biji kelor dan arang biji salak dalam penurunan kadar timbal $(\mathrm{Pb})$ pada air limbah dengan berbagai berat dapat dilihat :

Tabel 1

\begin{tabular}{|c|c|c|c|c|c|c|c|c|}
\hline \multirow[b]{2}{*}{ Berat (g) } & \multirow[b]{2}{*}{$\begin{array}{l}\text { Perla } \\
\text { kuan }\end{array}$} & \multirow[b]{2}{*}{$\begin{array}{c}\text { Kons. } \\
\text { AwalPb }\end{array}$} & \multicolumn{3}{|c|}{ BijiKelor } & \multicolumn{3}{|c|}{ BijiSalak } \\
\hline & & & $\begin{array}{l}\text { Kons. } \\
\text { Akhir }\end{array}$ & $\begin{array}{c}\text { BesarP } \\
\text { enu } \\
\text { runan }\end{array}$ & $\begin{array}{c}\text { Efesiensi } \\
\text { Penyerapan }\end{array}$ & $\begin{array}{l}\text { Kons. } \\
\text { Akhir }\end{array}$ & $\begin{array}{c}\text { Besar } \\
\text { Penuru } \\
\text { nan }\end{array}$ & $\begin{array}{c}\text { Efesiensi } \\
\text { Penyerapan }\end{array}$ \\
\hline 10 & 1 & 6,253 & 0,931 & 5,322 & 85,1111 & 0,974 & 5,279 & 84,4235 \\
\hline 10 & 2 & 6,253 & 1,138 & 5,115 & 81,8007 & 0,981 & 5,272 & 84,3115 \\
\hline 10 & 3 & 6,253 & 1,068 & 5,185 & 82,9202 & 1,596 & 4,657 & 74,4763 \\
\hline 10 & 4 & 6,253 & 0,951 & 5,302 & 84,7913 & 1,87 & 4,383 & 70,0944 \\
\hline 10 & 5 & 6,253 & 0,951 & 5,302 & 84,7913 & 1,697 & 4,556 & 72,861 \\
\hline 10 & 6 & 6,253 & 1,129 & 5,124 & 81,9447 & 0,975 & 5,278 & 84,4075 \\
\hline 10 & 7 & 6,253 & 0,992 & 5,261 & 84,1356 & 2,137 & 4,116 & 65,8244 \\
\hline \multirow[t]{2}{*}{10} & 8 & 6,253 & 0,996 & 5,257 & 84,0716 & 2,15 & 4,103 & 65,6165 \\
\hline & Mean & & 1,0195 & 5,233 & 83,6958 & 1,5475 & 4,7055 & 75,2518 \\
\hline
\end{tabular}

Besar Penurunan Kadar Pb pada Air Limbah menggunakan Arang Biji Kelor dan Arang Biji

Salak dengan Berat 10 gram

Berdasarkan tabel 1 dapat dilihat bahwa besar penurunan arang biji kelor yang teraktivasi terhadap logam limbah $\mathrm{Pb}$ dengan berat 10 gram ternyata memiliki konsentrasi minimum setelah dilakukan penyaringan adalah sebesar $0.931 \mathrm{ppm}$, penurunan minimum sebesar $5.115 \mathrm{ppm}$ serta efesiensi penyerapan minimum arang kelor sebesar $81.8007 \%$. Sedangkan konsentrasi maksimum setelah dilakukan penyaringan adalah sebesar 1.1380 ppm, konsentrasi penurunan maksimum sebesar 5.3220 ppm serta efesiensi penyerapan maksimum sebesar $85.1111 \%$. Sementara rata-rata konsentrasi akhir adalah sebesar 1.0195 ppm, rata-rata konsentrasi penurunan sebesar 5.2335 ppm dan rata-rata efesiensi penurunan sebesar $83.6958 \%$.

Berdasarkan tabel 1 dapat dilihat bahwa besar penurunan arang biji salak yang teraktivasi terhadap logam limbah $\mathrm{Pb}$ dengan berat 10 gram ternyata memiliki konsentrasi minimum setelah dilakukan penyaringan adalah sebesar $0.9740 \mathrm{ppm}$, penurunan minimum sebesar $4.1030 \mathrm{ppm}$ serta effesiensi penyerapan minimum arang salak sebesar $65.6165 \%$. Sedangkan konsentrasi maksimum setelah dilakukan 
penyaringan adalah sebesar $2.1500 \mathrm{ppm}$, konsentrasi penurunan maksimum sebesar $5.2790 \mathrm{ppm}$ serta efesiensi penurunan maksimum sebesar $84.4235 \%$. Sementara rata-rata konsentrasi akhir adalah sebesar 1.5475 ppm, rata-rata konsentrasi penurunan sebesar 4.7055 ppm dan rata-rata efesiensi penurunan sebesar $75.2518 \%$.

Tabel 2

Besar Penurunan Kadar Pb pada Air Limbah menggunakan Arang Biji Kelor dan Arang Biji

Salak dengan Berat 15 gram

\begin{tabular}{|c|c|c|c|c|c|c|c|c|}
\hline \multirow[b]{2}{*}{ Berat (g) } & \multirow[b]{2}{*}{$\begin{array}{l}\text { Perla } \\
\text { kuan }\end{array}$} & \multirow[b]{2}{*}{$\begin{array}{c}\text { Kons. } \\
\text { Awal } \\
\mathrm{Pb}\end{array}$} & \multicolumn{3}{|c|}{ BijiKelor } & \multicolumn{3}{|c|}{ BijiSalak } \\
\hline & & & $\begin{array}{l}\text { Kons. } \\
\text { Akhir }\end{array}$ & $\begin{array}{c}\text { Besar } \\
\text { Penu } \\
\text { runan }\end{array}$ & $\begin{array}{c}\text { Efesiensi } \\
\text { Penyerapan }\end{array}$ & $\begin{array}{l}\text { Kons. } \\
\text { Akhir }\end{array}$ & $\begin{array}{c}\text { BesarP } \\
\text { enurun } \\
\text { an }\end{array}$ & $\begin{array}{c}\text { Efesiensi } \\
\text { Penyerapan }\end{array}$ \\
\hline 10 & 1 & 6,253 & 0,889 & 5,364 & 85,7828 & 0,799 & 5,454 & 87,2221 \\
\hline 10 & 2 & 6,253 & 0,838 & 5,415 & 86,5984 & 0,795 & 5,458 & 87,2861 \\
\hline 10 & 3 & 6,253 & 0,726 & 5,527 & 88,3896 & 0,961 & 5,292 & 84,6314 \\
\hline 10 & 4 & 6,253 & 0,720 & 5,533 & 88,4855 & 0,871 & 5,382 & 86,0707 \\
\hline 10 & 5 & 6,253 & 0,825 & 5,428 & 86,8063 & 0,892 & 5,361 & 85,7348 \\
\hline 10 & 6 & 6,253 & 0,651 & 5,602 & 89,589 & 0,965 & 5,288 & 84,5674 \\
\hline 10 & 7 & 6,253 & 0,871 & 5,382 & 86,0707 & 1,116 & 5,137 & 82,1526 \\
\hline 10 & 8 & 6,253 & 0,525 & 5,728 & 91,604 & 0,929 & 5,324 & 85,1431 \\
\hline \multicolumn{3}{|c|}{ Mean } & 0,7556 & 5,4973 & 87,9157 & 0,9160 & 5,3370 & 85,3510 \\
\hline
\end{tabular}

Berdasarkan tabel 2 dapat dilihat bahwa besar penurunan arang biji kelor yang teraktivasi terhadap logam limbah $\mathrm{Pb}$ dengan berat 15 gram ternyata memiliki konsentrasi minimum setelah dilakukan penyaringan adalah sebesar $0.5250 \mathrm{ppm}$, penurunan minimum sebesar $5.3640 \mathrm{ppm}$ serta effesiensi penyerapan minimum arang kelor sebesar $85.7828 \%$. Sedangkan konsentrasi maksimum setelah dilakukan penyaringan adalah sebesar 0.8890 ppm, konsentrasi penurunan maksimum sebesar 5.7280 ppm serta efesiensi penurunan maksimum sebesar $91.6040 \%$. Sementara rata-rata konsentrasi akhir adalah sebesar $0.7556 \mathrm{ppm}$, rata-rata konsentrasi penurunan sebesar 5.4973 ppm dan rata-rata efsiensi penurunan sebesar $87.9157 \%$.

Tabel 3

Besar Penurunan Kadar Pb pada Air Limbah menggunakan Arang Biji Kelor dan Arang Biji Salak dengan Berat 20 gram

\begin{tabular}{cccccccccc}
\hline \multirow{2}{*}{ Berat $(\mathbf{g})$} & Perla & Kons. & & \multicolumn{3}{c}{ BijiKelor } \\
\cline { 5 - 10 } & kuan & Awal Pb & $\begin{array}{c}\text { Kons. } \\
\text { Akhir }\end{array}$ & $\begin{array}{c}\text { Besar } \\
\text { Penu } \\
\text { runan }\end{array}$ & $\begin{array}{c}\text { Efesiensi } \\
\text { Penyerapan }\end{array}$ & $\begin{array}{c}\text { Kons. } \\
\text { Akhir }\end{array}$ & $\begin{array}{c}\text { Besar } \\
\text { Penurunan }\end{array}$ & $\begin{array}{c}\text { Efesiensi } \\
\text { Penyerapan }\end{array}$ \\
\hline $\mathbf{1 0}$ & 1 & 6,253 & 0,489 & 5,764 & 92,1798 & 0,547 & 5,706 & 91,2522 \\
\hline $\mathbf{1 0}$ & 2 & 6,253 & 0,283 & 5,970 & 95,4742 & 0,547 & 5,706 & 91,2522 \\
\hline $\mathbf{1 0}$ & 3 & 6,253 & 0,370 & 5,883 & 94,0828 & 0,661 & 5,592 & 89,4291 \\
\hline $\mathbf{1 0}$ & 4 & 6,253 & 0,296 & 5,957 & 95,2663 & 0,465 & 5,788 & 92,5636 \\
\hline $\mathbf{1 0}$ & 5 & 6,253 & 0,312 & 5,941 & 95,0104 & 0,396 & 5,857 & 93,667 \\
\hline $\mathbf{1 0}$ & 6 & 6,253 & 0,312 & 5,941 & 95,0104 & 0,477 & 5,776 & 92,3717 \\
\hline $\mathbf{1 0}$ & 7 & 6,253 & 0,308 & 5,945 & 95,0744 & 0,485 & 5,768 & 92,2437 \\
\hline & 8 & 6,253 & 0,371 & 5,882 & 94,0668 & 0,465 & 5,788 & 92,5636 \\
\hline
\end{tabular}

bahwa besar penurunan arang biji salak yang teraktivasi terhadap logam limbah $\mathrm{Pb}$ dengan berat 15 gram ternyata memiliki konsentrasi minimum setelah dilakukan penyaringan adalah sebesar $0.7950 \mathrm{ppm}$, penurunan minimum sebesar 5.1370 ppm serta effesiensi penyerapan minimum arang salak sebesar $82.1526 \%$. Sedangkan konsentrasi maksimum setelah dilakukan penyaringan adalah sebesar $1.1160 \mathrm{ppm}$, konsentrasi penurunan maksimum sebesar 5.4580 ppm serta efesiensi penurunan maksimum sebesar $87.2861 \%$. Sementara rata-rata konsentrasi akhir adalah sebesar $0.9160 \mathrm{ppm}$, rata-rata konsentrasi penurunan sebesar $5.3370 \mathrm{ppm}$ dan rata-rata efesiensi penurunan sebesar $85.3510 \%$. 
Berdasarkan tabel 3 dapat dilihat bahwa besar penurunan arang biji kelor yang teraktivasi terhadap logam limbah $\mathrm{Pb}$ dengan berat 20 gram ternyata memiliki konsentrasi minimum setelah dilakukan penyaringan adalah sebesar $0.2830 \mathrm{ppm}$, penurunan minimum sebesar $5.7640 \mathrm{ppm}$ serta effesiensi penyerapan minimum arang kelor sebesar 92. $1798 \%$. Sedangkan konsentrasi maksimum setelah dilakukan penyaringan adalah sebesar $0.4890 \mathrm{ppm}$, konsentrasi penurunan maksimum sebesar 5.9700 ppm serta efesiensi penurunan maksimum sebesar $95.4742 \%$. Sementara rata-rata konsentrasi akhir adalah sebesar 0.3426 ppm, rata-rata konsentrasi penurunan sebesar 5.9103 ppm dan rata-rata efesiensi penurunan sebesar $94.5206 \%$.

Berdasarkan tabel 3 dapat dilihat bahwa besar serapan arang biji salak yang teraktivasi terhadap logam limbah $\mathrm{Pb}$ dengan berat 20 gram ternyata memiliki konsentrasi minimum setelah dilakukan penyaringan adalah sebesar $0.3960 \mathrm{ppm}$, penurunan minimum sebesar 5.5920 ppm serta effesiensi penyerapan minimum arang salak sebesar $89.4291 \%$. Sedangkan konsentrasi maksimum setelah dilakukan penyaringan adalah sebesar $0.6610 \mathrm{ppm}$, konsentrasi penurunan maksimum sebesar $5.8570 \mathrm{ppm}$ serta efesiensi penurunan maksimum sebesar $93.6670 \%$. Sementara rata-rata konsentrasi akhir adalah sebesar 0.5053 ppm, rata-rata konsentrasi penurunan sebesar $5.7476 \mathrm{ppm}$ dan rata-rata efesiensi penurunan sebesar $91.9178 \%$.

Tabel 4

Hasil analisis $\mathrm{T}$ independen Arang Biji Kelor dan Arang Biji Salak terhadap Limbah $\mathrm{Pb}$ dengan berbagai berat

\begin{tabular}{lcccc}
\hline & Arang & N & Mean & $\begin{array}{c}\text { Sig. (2- } \\
\text { tailed) }\end{array}$ \\
\hline 10 gram & Kelor & 8 & 5.2335 & \\
& Salak & 8 & 4.7055 & 0.022 \\
15 gram & Kelor & 8 & 5.4973 & \\
& Salak & 8 & 5.3370 & 0.014 \\
20 gram & Kelor & 8 & 5.9103 & \\
& Salak & 8 & 5.7476 & 0.001 \\
\hline
\end{tabular}

Pada tabel 4 dapat dilihat rata - rata penurunan 10 gram arang biji kelor adalah $5.2335 \mathrm{ppm}$, sedangkan untuk arang biji salak, rata - rata penurunan 10 gram adalah
$4.7055 \mathrm{ppm}$. Setelah dilakukan uji statistik didapatkan $p \leq \alpha(0.05)$, dan $p$ value sebesar $\mathrm{p}=0.022$ artinya ada perbedaan rata - rata penurunan 10 gram antara arang biji kelor dengan arang biji salak dalam menurunkan kadar limbah $\mathrm{Pb}$.

Pada tabel 4 dapat dilihat rata - rata penurunan 15 gram arang biji kelor adalah $5.4973 \mathrm{ppm}$, sedangkan untuk arang biji salak, rata - rata penurunan 15 gram adalah $5.3370 \mathrm{ppm}$. Setelah dilakukan uji statistik didapatkan $p \leq \alpha(0.05)$, dan $p$ value sebesar $\mathrm{p}=0.014$ artinya ada perbedaan rata - rata penurunan 15 gram antara arang biji kelor dengan arang biji salak dalam menurunkan kadar limbah $\mathrm{Pb}$.

Pada tabel 4 dapat dilihat rata - rata penurunan 20 gram arang biji kelor adalah 5.9103 ppm, sedangkan untuk arang biji salak, rata - rata penurunan 20 gram adalah $5.7476 \mathrm{ppm}$. Setelah dilakukan uji statistik didapatkan $p \leq \alpha(0.05)$, dan $p$ value sebesar $\mathrm{p}=0.001$ artinya ada perbedaan rata - rata penurunan 20 gram antara arang biji kelor dengan arang biji salak dalam menurunkan kadar limbah $\mathrm{Pb}$.

Hasil uji anova bertujuan untuk mengetahui perbedaan penurunan rata-rata dari masing-masing arang biji kelor dan arang biji salak dari berbagai masing masing berat dalam menurunkan kadar timbal $(\mathrm{Pb})$ pada air limbah.

\section{Tabel 5}

Hasil analisis Anova Arang Biji Kelor dan Arang Biji Salak terhadap Limbah $\mathrm{Pb}$ dengan berbagai berat

\begin{tabular}{lc}
\hline & Sig. \\
\hline Penurunan Limbah setelah disaring & .000 \\
arang kelor & \\
Penurunan Limbah setelah disaring & .000 \\
arang salak & \\
\hline
\end{tabular}

Pada tabel 5 terlihat bahwa hasil uji Anova diperoleh $\mathrm{p} \leq \alpha(0.05)$ untuk masing - masing perlakuan baik terhadap limbah yang disaring arang kelor maupun limbah yang disaring arang biji salak, dengan demikian Ho ditolak yang artinya ada 
perbedaan rata - rata penurunan dari ketiga perlakuan diantara arang biji kelor dan arang biji salak dalam menurunkan kadar limbah $\mathrm{Pb}$.

Tabel 6

Hasil analisis Test Bonferroni Penurunan Arang Biji Kelor dan Arang Biji Salak dalam menurunkan kadar $\mathrm{Pb}$ pada air limbah

\begin{tabular}{|c|c|c|c|}
\hline & $\begin{array}{l}\text { (I) } \\
\text { perlak } \\
\text { uan }\end{array}$ & $\begin{array}{l}(\mathrm{J}) \\
\text { perlak } \\
\text { uan }\end{array}$ & Sig. \\
\hline \multirow[t]{6}{*}{ penurunan Kelor } & 10 & 15 & .000 \\
\hline & & 20 & .000 \\
\hline & 15 & 10 & .000 \\
\hline & & 20 & .000 \\
\hline & 20 & 10 & .000 \\
\hline & & 15 & .000 \\
\hline \multirow[t]{6}{*}{ penurunan salak } & 10 & 15 & .001 \\
\hline & & 20 & .000 \\
\hline & 15 & 10 & .001 \\
\hline & & 20 & .040 \\
\hline & 20 & 10 & .000 \\
\hline & & 15 & .040 \\
\hline
\end{tabular}

Pada tabel 6 terlihat bahwa hasil uji Bonferroni diperoleh $\mathrm{p} \leq \alpha(0.05)$, maka H0 ditolak artinya ada perbedaan yang signifikan antara penurunan arang biji kelor dan arang biji salak. Yang mana kelompok yang berbeda signifikan pada penurunan arang biji kelor adalah penurunan 10 gr dengan 15 gr, 10 gr dengan 20 gr, dan 15 gr dengan 20 gr, sedangkan penurunan arang biji salak adalah pada penurunan $10 \mathrm{gr}$ dengan $15 \mathrm{gr}, 10 \mathrm{gr}$ dengan $20 \mathrm{gr}$, dan $15 \mathrm{gr}$ dengan 20 gr.

Berdasarkan hasil penelitian diperoleh rata - rata penurunan arang biji kelor dengan berat 10 gr terhadap limbah $\mathrm{Pb}$ adalah 5.2335 ppm dan rata-rata efesiensi penurunan sebesar $83.6958 \%$ dan rata rata penurunan arang biji salak dengan berat $10 \mathrm{gr}$ adalah $4.7055 \mathrm{ppm}$ dan rata-rata efesiensi penurunan sebesar $75.2518 \%$.

Sementara rata - rata penurunan arang biji kelor dengan berat 15 gr terhadap limbah $\mathrm{Pb}$ adalah $5.4973 \mathrm{ppm}$ dan rata-rata efesiensi penyerapan sebesar $87.9157 \%$ dan rata - rata penurunan arang biji salak dengan berat 15 gr adalah 5.3370 ppm dan rata-rata efesiensi penyerapan sebesar $85.3510 \%$.

Demikan pula rata - rata penurunan arang biji kelor dengan berat 20 gr terhadap limbah $\mathrm{Pb}$ adalah $5.9103 \mathrm{ppm}$ dan rata-rata efesiensi penyerapan sebesar $94.5206 \%$ dan rata - rata penurunan arang biji salak dengan berat 20 gr adalah 5.7476 ppm dan rata-rata efesiensi penyerapan sebesar $91.9178 \%$

Hasil uji $\mathrm{T}$ Independen dari ketiga perlakuan berat didapatkan $\mathrm{p} \leq \alpha(0.05)$, artinya ada perbedaan rata - rata penurunan dari ketiga perlakuan antara arang biji kelor dengan arang biji salak dalam menurunkan kadar limbah $\mathrm{Pb}$. Apabila dilihat rata- rata penurunan limbah $\mathrm{Pb}$ didapatkan 10 gr arang biji kelor adalah $5.2335 \mathrm{ppm}$, sedangkan untuk arang biji salak, rata - rata penurunan 10 gram adalah $4.7055 \mathrm{ppm}$. Sementara rata - rata penurunan dengan 15 gr arang biji kelor adalah 5.4973 ppm, sedangkan untuk arang biji salak, rata - rata penurunan 15 gr adalah $5.3370 \mathrm{ppm}$. Demikian pula rata - rata penurunan dengan 20 gr arang biji kelor adalah 5.9103 ppm, sedangkan untuk arang biji salak, rata - rata penurunan 20 gram adalah $5.7476 \mathrm{ppm}$. Dari ketiga perlakuan dengan masing masing berat yang sama terlihat arang biji kelor lebih efektif dibandingkan arang biji salak dalam menurunkan kadar $\mathrm{Pb}$ dalam air limbah.

Hasil uji Anova diperoleh $p \leq \alpha(0.05)$, dengan demikian maka Ho ditolak yang berarti rata-rata ketiga perlakuan tersebut memang berbeda nyata. Demikian pula dari hasil uji Bonferroni diperoleh nilai $\mathrm{p} \leq \alpha$ (0.05), yang berarti ada perbedaan yang signifikan antara penurunan arang biji kelor dan arang biji salak pada masing - masing berat dalam menurunkan kadar $\mathrm{Pb}$ pada air limbah. Yang mana kelompok yang berbeda signifikan pada penurunan arang biji kelor adalah penurunan $10 \mathrm{gr}$ dengan $15 \mathrm{gr}, 10 \mathrm{gr}$ dengan 20 gr, dan 15 gr dengan 20 gr, sedangkan penurunan arang biji salak adalah pada penurunan $10 \mathrm{gr}$ dengan $15 \mathrm{gr}$, 10 gr dengan 20 gr, dan 15 gr dengan 20 gr. 
Apabila dilihat rata-rata penurunan serapan terhadap limbah $\mathrm{Pb}$ baik pada berat 10 gr, 15 gr dan 20 gr menunjukkan bahwa penurunan paling besar terjadi pada berat 20 gr yaitu sebesar 5.9103 ppm dengan menggunakan arang biji kelor dan 5.7476 ppm dengan menggunakan arang biji salak Demikian pula dengan efesiensi penyerapan terbesar terjadi pada berat $20 \mathrm{gr}$ yaitu sebesar $94.5206 \%$ dengan menggunakan arang biji kelor dan 91.9178 $\%$ dengan menggunakan arang biji salak. Hal ini terjadi karena semakin kecil laju alir dan semakin banyak arang adsorben yang ditimbang maka semakin besar berat adsorben sehingga akan menambah tinggi adsorben pada kolom, dan akan semakin lama waktu kontak antara limbah dengan adsorben sehingga semakin banyak polutan yang terabsorbsi oleh adsorben. Hasil ini sesuai dengan penelitian Sri Lestari (2010) yang menyatakan terjadi peningkatan kadar $(\mathrm{Pb})$ yang teradsorpsi, penambahan berat adsorben mempengaruhi peningkatan kadar $(\mathrm{Pb})$ teradsorpsi. ${ }^{25}$

Adsorpsi merupakan peristiwa penyerapan di permukaan oleh suatu adsorben atau daya serap dari zat penyerap yang terjadi pada permukaan. Proses adsorpsi sangat sesuai untuk memisahkan bahan dengan konsentrasi yang kecil dari campuran yang mengandung bahan lain yang berkonsentrasi tinggi. ${ }^{20}$ Banyak senyawa yang dapat diadsorpsi oleh Adsorben dipengaruhi oleh sifat - sifat fisika dan kimia dari zat yang diserap, luas permukaan, jenis adsorbat, konsentrasi adsorbat, temperature, $\mathrm{pH}$, kecepatan pengadukan dan waktu kontak adsorpsi. ${ }^{21}$ Adsorpsi juga dipengaruhi oleh gugus fungsi, posisi gugus fungsi, ikatan rangkap, struktur rantai dan senyawa serapan. ${ }^{10} \mathrm{Biji}$ kelor lebih besar menurunkan penyerapan $\mathrm{Pb}$ dalam limbah dibandingkan biji salak, Hal ini dapat dilihat dari komposisi biji kelor yang mengandung selulosa dan memiliki kandungan lain ,yaitu zat aktif rhamnosyloxy - benzyl - isothiocyante, yang mampu mengadsorpsi dan menetralisir partikel - partikel lumpur serta logam yang terkandung dalam limbah tersuspensi dengan partikel kotoran yang melayang dalam air dan biji kelor juga mengandung polielektrik kationik dan flokulan alamiah yang dapat mengkoagulasi dan flokulasi kekeruhan air, dan komposisi biji salak hanya mengandung selulosa dan lignin. Penyerapan logam oleh adsorben melibatkan adanya kandungan lignin, selulosa serta zat aktif rhamnosyloxy benzyl - isothiocyante. Dengan adanya gugus fungsi pada senyawa organik tersebut, $\mathrm{H}^{+}$digantikan oleh ion logam dalam air limbah.

Biji kelor dan biji salak bukan hanya dapat menurunkan $\mathrm{Pb}$ saja tetapi juga terhadap logam lain seperti $\mathrm{Fe}, \mathrm{Cr}$, $\mathrm{Cd}$, dan sebagainya. Hal ini sesuai dengan penelitian Wahyu Kurniawan, dan Siti Tjahyani (2012) bahwa Biji kelor (MoringaOleifera) dengan kulit merupakan bahan tumbuhan yang juga dapat berfungsi sebagai adsorben untuk menurunkan kadar ion logam dalam air seperti ion besi $(\mathrm{Fe})$. Dalam penelitian ini dilakukan adsorpsi ion logam besi dalam air sungai Brantas oleh serbuk biji kelor ( moringa oleifera ) dengan menggunakan variasi massa $0,0000 \mathrm{~g} ; 0,2001 \mathrm{~g} ; 0,4000 \mathrm{~g}$; $0,6001 \mathrm{~g} ; 0,8001 \mathrm{~g}$ dan $1,0000 \mathrm{~g}$. Penentuan kadar ion besi yang teradsorpsi dilakukan dengan Spektro Fotometer Serapan Atom (SSA). Data yang diperoleh dianalisis secara deskriptif menggunakan persamaan adsorpsi isoterm. Kadar Fe hasil penelitian untuk variasi masa serbuk biji kelor tersebut di atas berturut - turut $6,0036 \% ; 69,0342$ $\%$; 85,0429\%; 89,0443\%; 91,5456 dan 92,5467\%. Hasil penelitian menunjukkan bahwa penurunan maksimum kadar ion besi yang teradsorpsi serbuk biji kelor diperoleh pada masa $1,0000 \mathrm{~g}$ yakni $92,5467 \% .^{25}$ Dan dalam penelitian Aji, B. K. dan Kurniawan, F, biji salak dimanfaatkan sebagai adsorben $\mathrm{Cr}(\mathrm{VI})$ dengan menggunakan metode kolom, serbuk biji salak diayak dengan ukuran partikel 125, 180, 250 dan $425 \mu \mathrm{m}$, dan hasil yang paling optimum adalah Ukuran adsorben biji salak berbanding terbalik dengan jumlah $\mathrm{Cr}(\mathrm{VI})$ yang teradsorpsi. Semakin kecil ukuran adsorben, semakin besar pula luas permukaan untuk mengadsorpsi. Ukuran optimum serbuk biji salak sebesar $125 \mu \mathrm{m}$ dengan presentase adsorpsi $\mathrm{Cr}(\mathrm{VI})$ sebesar 
45,2\% diperoleh dengan waktu kontak 60 menit, dan kapasitas penyerapan optimum ion $\mathrm{Cr}(\mathrm{VI})$ oleh serbuk biji salak adalah $0,59 \mathrm{mg} / \mathrm{g}$. Laju alir optimum adsorpsi $\mathrm{Cr}(\mathrm{VI})$ oleh adsorben biji salak adalah 1 $\mathrm{mL} /$ menit dengan prosentase $\mathrm{Cr}(\mathrm{VI})$ teradsorpsi sebesar 49,5\%. Semakin lambat laju alir, semakin besar pula tingkat adsorpsi. $^{12}$

Selain kadar karbon, proses adsorpsi juga dipengaruhi oleh sisi aktif dari permukaan adsorben yang biasa disebut aktivasi. Aktivasi adalah proses penambahan zat kimia (aktivator) yang bertujuan untuk membangun porositas dan memperbesar luas permukaan. Semakin tinggi konsentrasi aktivator semakin besar pula pengaruh untuk mengikat senyawa senyawa "tar" keluar melewati pori-pori sehingga volume pori-pori semakin luas. ${ }^{10}$ dengan demikian daya serapnya semakin besar pula.

Berdasarkan besar penurunan dan efesiensi penyerapan arang biji kelor aktif dan arang biji salak aktif, maka dapat disimpulkan bahwa arang biji kelor maupun arang biji salak aktif dapat dipergunakan sebagai adsorben terhadap limbah logam berat dan diantara keduanya yang lebih efektif adalah arang biji kelor dalam menurunkan kadar $\mathrm{Pb}$ dalam air limbah. Namun demikian untuk mengetahui kemampuan penyerapan logam dengan optimal tanpa regenerasi perlu dilakukan penelitian lebih lanjut tentang konsentrasi karbon aktif yang paling efektif dan berapa kali arang biji kelor maupun arang biji salak aktif dapat dipergunakan dalam menurunkan logam berat dengan optimal tanpa regenerasi serta dapat meneliti lebih lanjut dengan mengukur ukuran partikel dan waktu kontak pada adsorben arang biji kelor dan arang biji salak.

\section{SIMPULAN DAN SARAN}

Besar penurunan kadar $\mathrm{Pb}$ pada air limbah dengan menggunakan arang biji kelor teraktivasi sebesar 10 gr adalah 5.2335 ppm dengan efesiensi penyerapan sebesar $83.6958 \%$.

Besar penurunan kadar $\mathrm{Pb}$ pada air limbah dengan menggunakan arang biji salak teraktivasi sebesar 10 gr adalah $4.7055 \mathrm{ppm}$ dengan efesiensi penyerapan sebesar $75.2518 \%$.

Besar penurunan kadar $\mathrm{Pb}$ pada air limbah dengan menggunakan arang biji kelor teraktivasi sebesar 15 gr adalah 5.4973 ppm dengan efesiensi penyerapan sebesar $87.9157 \%$.

Besar penurunan kadar $\mathrm{Pb}$ pada air limbah dengan menggunakan arang biji salak teraktivasi sebesar 15 gr adalah 5.3370 ppm dengan efesiensi penyerapan sebesar $85.3510 \%$.

Besar penurunan kadar $\mathrm{Pb}$ pada air limbah dengan menggunakan arang biji kelor teraktivasi sebesar 20 gr adalah $5.9103 \mathrm{ppm}$ dengan efesiensi penyerapan sebesar $94.5206 \%$.

Besar penurunan kadar $\mathrm{Pb}$ pada air limbah dengan menggunakan arang biji salak teraktivasi sebesar $20 \mathrm{gr}$ adalah 5.7476 ppm dengan efesiensi penyerapan sebesar $91.9178 \%$.

Terdapat perbedaan rata - rata penurunan $10 \mathrm{gr}$ antara arang biji kelor dengan arang biji salak dalam menurunkan kadar $\mathrm{Pb}$ pada air limbah.

Terdapat perbedaan rata - rata penurunan 15 gr antara arang biji kelor dengan arang biji salak dalam menurunkan kadar $\mathrm{Pb}$ pada air limbah.

Terdapat perbedaan rata - rata penurunan 20 gr antara arang biji kelor dengan arang biji salak dalam menurunkan kadar $\mathrm{Pb}$ pada air limbah.

Terdapat perbedaan penurunan kadar $\mathrm{Pb}$ pada air limbah dengan menggunakan arang biji kelor teraktivasi dan arang biji salak teraktivasi.

Untuk penurunan penyerapan logam $\mathrm{Pb}$ pada air limbah dapat disarankan menggunakan arang biji kelor dan arang biji salak 20 gr.

Perlu dilakukan penelitian lebih lanjut tentang konsentrasi karbon aktif yang palingefektif.

Perlu dilakukan penelitian lebih lanjut dengan mengukur ukuran partikel dan waktu kontak pada adsorben arang biji kelor dan arang biji salak. 


\section{DAFTAR PUSTAKA}

Wikipedia. Percetakan. 2014. [diakses 28 januari 2014]. Tersedia dari:URL:http://id.wikipedia.org/wiki/ Percetakan

Keputusan Menteri Pertanian.laporan pemantauan limbah cair kegiatan/usaha dan atau industri pertanian.UU Menteri Pertanian 818 tahun 1998

Wiskandini Yunaska Ridaningtiyas, Setiyo Didik Widodo, Hastuti Rum. Pengolahan Limbah Cair Industri Percetakan Secara Elektrolisis dengan Elektroda Karbon/karbon. Semarang : Universitas Diponegoro. 2013

Ririn. Degradasi Zat Warna Rhodamin b dengan AOPs Metode Fenton berdasarkan Variasi Konsentrasi $\mathrm{Fe}^{2+}$. Semarang: Universitas Muhammadiyah Semarang. 2010

Komunitas Software. Tinta (Sejarah, bahan, dan kandungan kimia). 2013. [diakses 28 januari 2014]. Tersedia dari : URL : http://masbadar.com/tinta-sejarahbahan-dan-kandungan-kimia-nya/.

Suksmerri, Sugiarta Evino. Analisis Resiko Lingkungan pada Perusahaan Media Cetak di Kota Padang tahun 2012. Padang : Politeknik Kesehatan Padang. 2012

Ardyanto Denny. Deteksi Pencemaran Timah Hitam $(\mathrm{Pb})$ dalam Darah Masyarakat yang Terpajan Timbal (Plumbum). Surabaya : Universitas Airlangga. 2007

Prayitno Edi. Bahaya timbal bagi kesehatan. 2012. [ diakses 29 januari 2014]. Tersedia dari : URL : http://hex-

a.blogspot.com/2012/09/bahayatimbal-bagi-kesehatan.html:FOSS Informatika

Suprihatin, A Erriek. Biosorpsi Logam $\mathrm{Cu}(\mathrm{II})$ dan $\mathrm{Cr}$ (VI ) pada Limbah Elektroplating dengan Menggunakan Biomasa Phanerochaete Chrysosporium. Yogyakarta : Universitas Pembangunan Nasional. 2009
Erdinur. Pemanfaatan Biosorben Arang Sekam Padi dengan Metode Aktivasi terhadap Penyerapan Logam Berat. Padang: Politeknik Kesehatan Padang. 2012

Departemen Pertanian. Kawasan Salak. Jurnal Pertanian Direktur Budidaya Tanaman Buah. 2009

Aji, Kurniawan. Pemanfaatan Serbuk Biji Salak (Salacca zalacca) sebagai Adsorben Cr(VI) dengan Metode Batch dan Kolom. Surabaya : Institut Teknologi Sepuluh November. 2012

Arnas Ika Puji Astutik. Pengaruh Suhu Interaksi Minyak Goreng Bekas dengan Menggunakan Karbon Aktif Biji Kelor (Moringa oleifera. LAMK) terhadap Angka Iodin dan Angka Peroksida. Malang : UIN Malang. 2010

Sri Rozanna Irianty. Pengaruh Massa Biji Kelor (Moringa oleifera Lamk) Dan Waktu Kontak pada Pengolahan Air Gambut. Riau : Univeritas Riau. 2010

Soeparman h.m ,Suparmin. Pembuangan Tinja dan Limbah. Jakarta : EGC . 2001

Keputusan Menteri Negara Lingkungan Hidup. Baku Mutu Limbah Cair. NOMOR : KEP- 51/MENLH/10/1995

Djabu Udin, dkk. Pedoman bidang Studi Pembuangan Tinja dan Air Limbah pada Institusi Pendidikan Sanitasi Kesling. Jakarta : Departemen Kesehatan RI. 1990/1991

Widowati Wahyu, Sastiono Astiana, Jusuf Rymond Rumampuk. Efek Toksik Logam, Pencegahan dan Penanggulan Pencemaran. Yogyakarta : Andi. 2008

Edahwati Luluk, Suprihatin. Kombinasi Proses Aerasi, Adsorpsi, Dan Filtrasi Pada Pengolahan Air Limbah Industri Perikanan. Jawa Timur : Upn. 2005

Tandy Edward, Fahmi Ismail Hasibuan, Harahap Hamidah. Kemampuan Adsorben Limbah Lateks Karet Alam Terhadap Minyak Pelumas Dalam Air. Medan : USU. 2012

Kurniawan, Wahyudi, Tjahyani Siti. Adsorpsi Ion Logam Besi Dalam Air Sungai Brantas Oleh Serbuk Biji Kelor (Moringa oleifera). Surabaya: UNESA. 2012 
PERBEDAAN ARANG BIJI KELOR DAN ARANG BIJI SALAK DALAM.. | ABDI ISWAHYUDI YASRIL

Lestari,Sri. Pengaruh Berat Badan Waktu Kontak untuk Adsorpsi Timbal oleh Adsorben dari Kuli t Batang Jambu Biji (PsidiumGuajava L). Universitas Mulawarman.2010 
JURNAL ILMIAH KESEHATAN MEDIAHUSADA | VOLUME 07/NOMOR 01/MARET 2018 